\title{
Correction to: Moonlighting protein prediction using physico-chemical and evolutional properties via machine learning methods
}

\author{
Farshid Shirafkan ${ }^{1}$, Sajjad Gharaghani ${ }^{1^{*}}$, Karim Rahimian ${ }^{2}$, Reza Hasan Sajedi ${ }^{3}$ and Javad Zahiri ${ }^{4,5^{*}}$
}

\section{The original article can be found online at https://doi. org/10.1186/s12859-021- 04194-5.}

\section{${ }^{*}$ Correspondence:}

s.gharaghani@ut.ac.ir; jzahiri@health.ucsd.edu

${ }^{1}$ Laboratory of Bioinformatics and Drug Design,

Institute of Biochemistry and Biophysics, University of Tehran, Tehran, Iran

${ }^{4}$ Department of Neuroscience, University of California San Diego, La Jolla, CA, USA

Full list of author information is available at the end of the article

\section{Correction to: BMC Bioinformatics (2021) 22:261} https://doi.org/10.1186/s12859-021-04194-5

Following the publication of the original article [1], the authors identified that Dr. Javad Zahiri was not assigned as the co-corresponding author in the published article.

The original article [1] has been corrected.

\begin{abstract}
Author details
${ }^{1}$ Laboratory of Bioinformatics and Drug Design, Institute of Biochemistry and Biophysics, University of Tehran, Tehran, Iran. ${ }^{2}$ Bioinformatics and Computational Omics Lab (BioCOOL), Department of Biophysics, Faculty of Biological Sciences, Tarbiat Modares University, Tehran, Iran. ${ }^{3}$ Department of Biochemistry, Faculty of Biological Sciences, Tarbiat Modares University, Tehran, Iran. ${ }^{4}$ Department of Neuroscience, University of California San Diego, La Jolla, CA, USA. ${ }^{5}$ Department of Pediatrics, University of California San Diego, La Jolla, CA, USA.
\end{abstract}

Published online: 09 July 2021

Reference

1. Shirafkan, et al. Moonlighting protein prediction using physico-chemical and evolutional properties via machine learning methods. BMC Bioinformatics. 2021;22:261. https://doi.org/10.1186/s12859-021-04194-5.

\section{Publisher's Note}

Springer Nature remains neutral with regard to jurisdictional claims in published maps and institutional affiliations. author(s) and the source, provide a link to the Creative Commons licence, and indicate if changes were made. The images or other third party material in this article are included in the article's Creative Commons licence, unless indicated otherwise in a credit line to the material. If material is not included in the article's Creative Commons licence and your intended use is not permitted by statutory regulation or exceeds the permitted use, you will need to obtain permission directly from the copyright holder. To view a copy of this licence, visit http:// creativecommons.org/licenses/by/4.0/. The Creative Commons Public Domain Dedication waiver (http://creativecommons.org/publi cdomain/zero/1.0/) applies to the data made available in this article, unless otherwise stated in a credit line to the data. 